\section{Role of Sugar in the Vase Solution on Postharvest Flower and Leaf Quality of Oriental Lily 'Stargazer'}

\author{
Susan S. Han \\ Department of Plant and Soil Sciences, French Hall, University of \\ Massachusetts, Amherst, MA 01003-2910
}

Additional index words. Lilium sp., foliar chlorosis, bud opening, bud blasting, bud stage, vase life

\begin{abstract}
Individual 'Stargazer' flowers lasted about 4.5 to 5 days and weighed $\approx 14 \mathrm{~g}$. Addition of $2 \%$ sugar into the vase solution neither affected the longevity nor the size of the flowers but significantly enhanced anthocyanin content and, thus, the intensity of petal color. Defoliation of Oriental lilies, the common practice of retail florists, did not affect the opening, longevity, and size of the open flowers, but did result in lighter-color petals when placed in a solution without sugar. Addition of sugar to the vase solution counteracted the adverse effects of defoliation on petal color. Sugar in the vase solution did not overcome the increased bud blasting and the reduced longevity and size of flowers induced by cold storage. However, it enabled more flowers to open fully, which, without sugar, remained only partially open. Excised bud experiments revealed that bud size of $6.1 \mathrm{~cm}$ and $7.0 \mathrm{~cm}$ were critical for opening of non-cold-stored and cold-stored buds, respectively. Unlike other cut flower species in which flowers for long-term storage or long-distance transport are harvested at a tighter-bud stage than those intended for the local market, in 'Stargazer', harvesting of stems where the smallest bud is $>7.0 \mathrm{~cm}$ would be critical in reducing cold-storage-induced bud blasting.
\end{abstract}

Sucrose is the major form of photosynthetically assimilated carbon that is transported in plants (Lalonde et al., 1999) and is the major source of carbon for petal growth (Woodson and Wang, 1987). The accumulation of reducing sugars (Nichols, 1973), in conjunction with an increase in invertase activities during petal expansion (Woodson and Wang, 1987), results in a low ratio of sucrose to reducing sugars which then allows a continuous transport of sucrose into the growing petals. In Asiatic lilies, the total carbohydrates in the tepals of each bud plays an important role in the development of the buds to anthesis (van der Meulen-Muisers et al., 2001). Smaller buds, detached from the inflorescence, contain less stored carbohydrates and have a higher percentage of bud blasting. This led to the suggestion that bud blasting in Asiatic lily is due to a lack of carbohydrates as has been reported in Freesia $\times$ hybrida Bailey (Spikman, 1989) and Gladiolus sp. (Serek et al., 1994). In comparison, when buds of Asiatic lily are left attached, redistribution of stored carbohydrates from larger buds to smaller buds occurs within the inflorescence and enables small buds ( 30 to $60 \mathrm{~mm}$ ), which would have blasted if detached, to develop to anthesis (van der Meulen-Muisers et al., 2001).

In flowers containing anthocyanins, the change in $\mathrm{pH}$ of the vacuoles determines the

Received for publication 15 Apr. 2002. Accepted for publication 30 Sept. 2002. Publication no. 3299 of the Massachusetts Agr. Expt. Sta. I thank Montgomery Rose, in Hadley, Mass., for donation of the cut flowers and the Association of Specialty Cut Flower Growers and the New England Greenhouse Conference for partially funding this project. I am also grateful to Joel H. Benton and Jonathan A. Miller for their technical assistance. color change of the senescing petals (Stewart et al., 1975). A slight change in $\mathrm{pH}$ affects the copigmentation of anthocyanin with other flavonoids and related compounds, thus resulting in an array of colors from red to blue (Asen, 1975). Treatment of cut flowers with sugar delays proteolysis which then delays the increase in $\mathrm{pH}$ and bluing of petals associated with senescence (Halevy and Mayak, 1979).

One of the advantages of cut flowers is that, after harvesting, sucrose can be supplied in the vase solution to improve the quality and postharvest life of many species (Halevy and Mayak, 1979). The objective of this study was to investigate if addition of sugars to the vase solution could counteract the bud blasting of small lily buds and how sugars affect the quality of the leaves and the opening, petal color, and longevity of Oriental lily 'Stargazer' flowers.

\section{Materials and Methods}

Concentration of sugar and cold storage. Cut Oriental lilies 'Stargazer' were harvested from local commercial greenhouses when the largest flower bud on each stem was at the stage of showing color to fully colored. They were transported, within an hour, to a $20^{\circ} \mathrm{C}$ laboratory and each stem was trimmed to $45 \mathrm{~cm}$ and then placed, for postharvest evaluation, in an individual $100-\mathrm{mL}$ tube containing $0 \%$ or $2 \%$ sugar plus $200 \mathrm{mg} \cdot \mathrm{L}^{-1}$ hydroxyquinoline citrate (HQC) or was cold-stored for 2 weeks prior to placing in the preservative solutions. Coldstored stems were sleeved and stored dry in a $3.3{ }^{\circ} \mathrm{C}$ dark cooler for 2 weeks. In a separate experiment to determine the effects of $\mathrm{GA}_{4+7}$ and BA in reducing leaf yellowing induced by sugar in the vase solution, cut stems were sprayed to runoff with water (control) or with a solution containing $50 \mathrm{mg} \cdot \mathrm{L}^{-1}$ each of $\mathrm{GA}_{4+7}$ and BA. Stems were then placed in tubes containing $0 \%$ or $2 \%$ sugar plus $200 \mathrm{mg} \cdot \mathrm{L}^{-1} \mathrm{HQC}$.

Postharvest quality of the flowers and leaves was evaluated in a $20{ }^{\circ} \mathrm{C}$ simulated interior environment illuminated $12 \mathrm{~h} / \mathrm{d}$ with $8 \mu \mathrm{mol} \cdot \mathrm{m}^{-2} \cdot \mathrm{s}^{-1}$ from cool-white fluorescent lamps. The development of leaf yellowing, longevity of each flower bud, percentage of bud blasting, and the vase life of each stem was monitored. Vase life was defined as the number of days from placing the stems in the vase to the day when the last flower bud on each stem senesced. Leaves were considered senesced when $>50 \%$ of the area had become chlorotic or necrotic. There were eight replicate stems per treatment.

For excised bud experiments, various stages (based on length of the flower buds) of individual buds with the pedicel attached were placed in $20-\mathrm{mL}$ vials containing various concentrations of sugar and $200 \mathrm{mg} \cdot \mathrm{L}^{-1} \mathrm{HQC}$. Coldstored buds were placed in vials containing 200 $\mathrm{mg} \cdot \mathrm{L}^{-1} \mathrm{HQC}$ for the 2-week storage and were then transferred to the appropriate preservative solutions for postharvest evaluation. There were 10 replicate buds per stage.

Leaf removal experiment. To determine the role of leaves on bud development, leaves were removed from freshly harvested stems. Control stems were left intact. Each stem was then placed in tubes containing $0 \%$ or $2 \%$ sugar plus $200 \mathrm{mg} \cdot \mathrm{L}^{-1} \mathrm{HQC}$. There were eight replicate stems per treatment.

Anthocyanin. Anthocyanin content was determined using modified procedures of Dedaldechamp et al. (1995). Cut stems were placed in tubes containing $0 \%, 2 \%$, or $5 \%$ sugar plus $200 \mathrm{mg} \cdot \mathrm{L}^{-1} \mathrm{HQC}$. Once fully opened (the day after anthesis), flowers were excised and their petals removed and weighed. Petals were then cut into $\approx 1-\mathrm{cm}$ strips, placed in a beaker containing $0.1 \% \mathrm{HCl}$ in methanol, and ground to an even consistency. The resulting slurry of petal and methanol was then vacuum filtered and rinsed sufficiently with $0.1 \% \mathrm{HCl}$ in methanol solution to remove remaining pigments. Filtrate was adjusted to $1: 100 \mathrm{w} / \mathrm{v}$ using additional $0.1 \% \mathrm{HCl}$ in methanol solution. Absorbance was measured with a spectrophotometer (Spectronic model 1201, Rochester, N.Y.) at $530 \mathrm{~nm}$. The amount of anthocyanin in the most mature bud (referred to as the position 1 bud) on stems placed in sugarless solutions was used as the reference point for calculations. Data are expressed as the percentage of anthocyanin in each bud relative to the position 1 bud.

Statistical analysis. Data were analyzed using the SAS General Linear Model procedure (SAS Institute, 1999). An arcsin transformation was performed on percentage data prior to analysis. Differences among treatments were further analyzed using Duncan's multiple range test or paired comparison.

\section{Results and Discussion}

Sugar and opening of flowers. Individual 'Stargazer' flowers lasted $\approx 4.5$ to $5 \mathrm{~d}$ and weighed $\approx 14 \mathrm{~g}$ (Table 1 ). Unlike cut roses, in 
which addition of sugar increases the fresh and dry weight of the petals (Goszczynska et al., 1990), the addition of $2 \%$ sugar into the vase solution did not affect the size of 'Stargazer' flowers (Table 1). Longevity of each flower, another measure of the postharvest quality of flowers, was not affected by the developmental stage of the buds at harvest or the sugar in the vase solution (Table 1). In Asiatic lily, longevity remained constant for all buds that are attached to the inflorescence, despite their vast differences in developmental stages at the time of harvest (Song et al., 1996; van der MeulenMuisers et al., 2001). However, longevity decreased as the size of detached buds decreased at the time of harvest (van der Meulen-Muisers et al., 2001). The authors suggested that the constant longevity of all attached flowers in a lily inflorescence is due to the redistribution of tepal carbohydrates from the larger to the smaller buds which would not have occurred in detached buds. The proposed role of carbohydrate redistribution in flower longevity was not observed in 'Stargazer', since there was no difference in longevity between attached and detached flowers and between various stages of detached buds (data not shown). The discrepancy between Asiatic lilies and 'Stargazer' was probably due to the large differences in the number of flower buds. In Asiatic lily, each stem had 5 to 15 flower buds (Song et al., 1996; van der Meulen-Muisers and van Oeveren, 1997), whereas in 'Stargazer', each stem contained three to four buds. It is possible that even the smallest bud on 'Stargazer' stems harvested at the commercial stage contained sufficient carbohydrates for the opening of the buds. The addition of sugar to the vase solution $(0.5 \%$ to $2 \%$ ), therefore, did not improve the longevity of excised 'Stargazer' buds (data not shown). However, while sugar in the vase solution did not affect the flower longevity of Asiatic lily 'Corderia', it does increase the percentage of open buds, thus, significantly increasing the vase life (Song et al., 1996). The effects of sugar in extending vase life was not observed in 'Stargazer' as all buds developed into anthesis, regardless of sugar in the solution, and the longevity of all flowers was the same. The average vase life of the cut stems was $17.5 \mathrm{~d}$.

Sugar, however, significantly increased the anthocyanin content in 'Stargazer' petals and thus the intensity of the petal color (Table 2). At the time when the flowers were fully opened (the day after anthesis), anthocyanin content in the $2 \%$ sugar treatment was $\approx 160 \%$ that of those placed in $0 \%$ sugar, giving the petals a visual appearance close to those on intact plants. Increasing the sugar concentration to $5 \%$ further increased the anthocyanin content. A low sugar content has been associated with pale-colored flowers (Kofranek, 1985). In contrast, environmental conditions such as low temperature and high light intensity that result in sugar accumulation increase the synthesis of anthocyanin and the color intensity of petals (Boo et al., 1997). A positive correlation exists between soluble sugar content and anthocyanin in Eustoma grandiflorum (Ref.) Shinn. petals (Kawabata et al., 1999). It is believed that sugar does not act

Table 1. Effects of cold storage, sugar in the vase solution, and bud position on longevity and mass of the open flowers of Oriental lily 'Stargazer'. Cut stems were placed in solutions containing $0 \%$ or $2 \%$ sugar plus $200 \mathrm{mg} \cdot \mathrm{L}^{-1} \mathrm{HQC}$. Half of the stems were placed in a $3.3{ }^{\circ} \mathrm{C}$ room for 2 weeks. Fresh weight was collected the day after anthesis when the flowers were fully opened. Data are means \pm SE of eight replicate stems.

\begin{tabular}{lcccc}
\hline $\begin{array}{l}\text { Cold storage } \\
\text { (weeks) }\end{array}$ & $\begin{array}{c}\text { Sugar } \\
(\%)\end{array}$ & $\begin{array}{c}\text { Bud } \\
\text { position }\end{array}$ & $\begin{array}{c}\text { Longevity } \\
(\text { days })\end{array}$ & $\begin{array}{c}\text { Fresh wt } \\
(\mathrm{g})\end{array}$ \\
\hline 0 & 0 & 1 & $4.8 \pm 0.5$ & $14.8 \pm 0.7$ \\
0 & 0 & 2 & $5.8 \pm 0.6$ & $13.6 \pm 0.8$ \\
0 & 0 & 3 & $5.0 \pm 0.6$ & $12.7 \pm 0.4$ \\
0 & 2 & 1 & $3.8 \pm 0.2$ & $14.7 \pm 0.7$ \\
0 & 2 & 2 & $4.8 \pm 0.4$ & $14.0 \pm 0.6$ \\
0 & 2 & 3 & $4.8 \pm 0.5$ & $13.5 \pm 0.5$ \\
2 & 0 & 1 & $3.0 \pm 0.3$ & $8.5 \pm 1.1$ \\
2 & 0 & 2 & $4.0 \pm 0$ & $9.8 \pm 0.9$ \\
2 & 0 & 3 & $---y$ & --- \\
2 & 2 & 1 & $3.2 \pm 0.3$ & $10.8 \pm 0.6$ \\
2 & 2 & 2 & $3.3 \pm 0.2$ & $10.4 \pm 0.6$ \\
2 & 2 & 3 & --- & --- \\
& & ANOVA & & $* * *$ \\
Storage & & & $* *$ & NS \\
Sugar & & & NS & NS \\
Bud position & & NS & NS \\
Storage*Sugar & & & NS & NS \\
Storage*Position & & & NS & NS \\
Sugar*Position & & & NS & NS \\
Storage*Sugar*Position & & & &
\end{tabular}

${ }^{2} 1$ = largest bud, 2 = second largest bud, and $3=$ third largest bud.

${ }^{y}$ All of the buds aborted.

Ns, ${ }^{* *}, * * *$ Nonsignificant or significant at $P \leq 0.01$ or 0.001 , respectively.

as the specific signal for the activation of the anthocyanin biosynthesis gene expression but rather as a source for carbohydrate metabolism, specifically phosphorylation of hexose, upon which the induction of anthocyanin synthesis is dependent (Moalem et al., 1997; Vitrac et al., 2000). Furthermore, it has been shown that the sugar-phosphorylation-related signal transduction must interact with the gibberellin signal to induce gene expression and anthocyanin accumulation in developing corollas (Moalem et al., 1997; Neta et al., 2000).

The practice of defoliating Oriental lilies, customary of retail florists, did not affect the opening (all buds developed to anthesis, regardless of treatment), flower longevity, or size of the open flowers (Table 3), but did result in, visibly lighter-color petals when placed in a solution without sugar. Addition of sugar into the vase solution counteracted the adverse effects of defoliation on petal color. In addition, sugar in the vase solution increased the flower size of the defoliated stems (Table 3). It has been reported that defoliation does not affect bud opening or flower longevity in Asiatic lilies and thus the conclusion that carbohydrates stored in the leaves do not contribute much to maintaining flower longevity (van der Meulen-Muisers et al., 1995). Our data indicated that while carbohydrates stored in the leaves of 'Stargazer' did not affect the opening and longevity of the flowers, it played a role in the synthesis of anthocyanins in developing buds. Translocation of carbohydrates from stem and leaves to the developing buds for anthocyanin synthesis is supported by a study in Eustoma, in which shading of the stem and leaf significantly reduced the intensity of petal color, whereas shading of the opening buds did not (Kawabata et al., 1999).
The bud blasting and reduced longevity and size of flowers induced by cold storage (Han, 2001) was not affected by the addition of sugar in the vase solution (data not shown). Sugar in the vase solution, however, enabled $15 \%$ to $20 \%$ more flowers in cold-stored stems to open fully vs. only partially without sugar. This suggests that addition of exogenous sugar to the vase solution affects the opening of buds but only in situations when the stored carbohydrates are borderline limited.

The role of sugar in flower opening is more evident in excised bud experiments. Without sugar, $100 \%$ of the freshly harvested buds $\leq 6.1 \mathrm{~cm}$ blasted, whereas $60 \%$ and $0 \%$ of the buds $6.6 \mathrm{~cm}$ and $>7.0 \mathrm{~cm}$, respectively, blasted (Fig. 1). The addition of $2 \%$ sugar en-

Table 2. Effects of sugar and bud position on anthocyanin content in petals of Oriental lily 'Stargazer'. Petals were extracted in $0.1 \% \mathrm{HCl}$ in methanol and absorbance was measured with a spectrophotometer at $530 \mathrm{~nm}$.

\begin{tabular}{lccc}
\hline $\begin{array}{l}\text { Sugar } \\
(\%)\end{array}$ & $\begin{array}{c}\text { Bud } \\
\text { position }^{\mathrm{z}}\end{array}$ & $\begin{array}{c}\text { Fresh wt } \\
(\mathrm{g})\end{array}$ & $\begin{array}{c}\text { Anthocyanin } \\
\text { content }^{\mathrm{y}}(\%)\end{array}$ \\
\hline 0 & 1 & $15.2 \mathrm{a}^{\mathrm{x}}$ & $100 \mathrm{~cd}$ \\
0 & 2 & $14.4 \mathrm{a}$ & $99.1 \mathrm{~cd}$ \\
0 & 3 & $13.2 \mathrm{a}$ & $69.3 \mathrm{~d}$ \\
2 & 1 & $15.1 \mathrm{a}$ & $156.6 \mathrm{bc}$ \\
2 & 2 & $14.7 \mathrm{a}$ & $160.1 \mathrm{bc}$ \\
2 & 3 & $15.4 \mathrm{a}$ & $163.9 \mathrm{~b}$ \\
5 & 1 & $14.1 \mathrm{a}$ & $202.7 \mathrm{ab}$ \\
5 & 2 & $13.3 \mathrm{a}$ & $193.2 \mathrm{ab}$ \\
5 & 3 & $14.5 \mathrm{a}$ & $227.3 \mathrm{a}$ \\
\hline
\end{tabular}

${ }^{\mathrm{z}} 1=$ largest bud, $2=$ second largest bud, and $3=$ third largest bud.

${ }^{y}$ Expressed as the percentage of anthocyanin content in bud number one of the stems placed in $0 \%$ sugar solution.

${ }^{x}$ Letters indicate significance among treatments within each column, determined by Duncan's multiple range test at $P=0.05$. 
Table 3. Effects of defoliation on longevity and size of open flowers as well as the vase life of the cut Oriental lily 'Stargazer'. Leaves on the cut stems were left intact or removed and the cut stems were placed in solutions containing $0 \%$ or $2 \%$ sugar plus $200 \mathrm{mg} \cdot \mathrm{L}^{-1} \mathrm{HQC}$. Data are means \pm SE of eight replicates.

\begin{tabular}{|c|c|c|c|c|c|c|c|c|}
\hline \multirow[b]{2}{*}{ Leaves } & \multirow{2}{*}{$\begin{array}{c}\text { Sugar } \\
(\%)\end{array}$} & \multicolumn{3}{|c|}{ Longevity (days) } & \multicolumn{3}{|c|}{ Fresh wt (g) } & \multirow{2}{*}{$\begin{array}{c}\text { Vase life } \\
\text { (days) }\end{array}$} \\
\hline & & Bud 1 & Bud 2 & Bud 3 & Bud 1 & Bud 2 & Bud 3 & \\
\hline Intact & 0 & $4.8 \pm 0.5$ & $5.8 \pm 0.6$ & $5.0 \pm 0.6$ & $14.8 \pm 0.7$ & $13.6 \pm 0.8$ & $12.7 \pm 0.5$ & $17.8 \pm 0.9$ \\
\hline Intact & 2 & $3.8 \pm 0.2$ & $4.8 \pm 0.4$ & $4.8 \pm 0.5$ & $14.7 \pm 0.7$ & $14.0 \pm 0.6$ & $13.5 \pm 0.5$ & $17.5 \pm 0.9$ \\
\hline Defoliated & 0 & $4.6 \pm 0.4$ & $5.3 \pm 0.6$ & $5.0 \pm 0.7$ & $14.2 \pm 0.7$ & $13.5 \pm 0.6$ & $11.7 \pm 0.3$ & $18.1 \pm 0.3$ \\
\hline Defoliated & 2 & $4.3 \pm 0.4$ & $4.6 \pm 0.8$ & $4.9 \pm 0.4$ & $16.1 \pm 0.6$ & $15.7 \pm 0.6$ & $13.3 \pm 0.6$ & $19.0 \pm 0.3$ \\
\hline \multicolumn{9}{|l|}{ Paired comparison } \\
\hline Intact vs. Defoliation & & NS & NS & NS & NS & NS & NS & NS \\
\hline Intact stems, Sugar $0 \%$ vs. $2 \%$ & & NS & NS & NS & NS & NS & NS & NS \\
\hline Defoliated stems, Sugar $0 \%$ vs. $2 \%$ & & NS & NS & NS & NS & $*$ & $*$ & NS \\
\hline
\end{tabular}

Ns, *Nonsignificant or significant at $P \leq 0.05$, respectively.

abled most of the buds between 5.4 and 6.6 $\mathrm{cm}$ to open indicating that lack of sugar was the cause for bud blasting in non-cold-stored buds. For smaller buds, i.e., $4.2 \mathrm{~cm}$, it was necessary to increase the sugar concentration to $5 \%$ in order to eliminate bud blasting (data not shown). The concentration of exogenous sugar required to overcome bud blasting was dependent on the developmental stage of the buds and decreased as the bud size increased (Fig. 2). Our data agree with that of Asiatic lily in which a bud size of $>6.0 \mathrm{~cm}$ was necessary for the opening of the detached buds (van der Meulen-Muisers et al., 2001). However, the positive correlation between the developmental stage of the buds, thus the total carbohydrates in the tepals, and the longevity of detached Asiatic lily buds (van der Meulen-Muisers et al., 2001) was not observed in 'Stargazer'. The longevity was the same for all detached buds of 'Stargazer' that developed into anthesis, regardless of their size at the time of harvest (data not shown). This suggests that buds of that stage contain sufficient carbohydrates for maintaining flower longevity.

The cold-storage-induced bud blasting in intact Oriental lilies (Han, 2001) was observed in excised buds as well. Blasting of $7.0-\mathrm{cm}$ buds in $0 \%$ sugar increased from $0 \%$ to $40 \%$ after a 2-week cold storage (Fig. 3). Addition of $2 \%$ sugar in the vase solution, however, counteracted the detrimental effects of cold storage on larger buds and all buds at the 7.0$\mathrm{cm}$ stage developed into anthesis. For smaller buds, sugar alone did not counteract the negative effects of cold storage on bud blasting. All of the freshly harvested $5.4-\mathrm{cm}$ buds, which would have developed into anthesis in a $2 \%$ sugar solution, failed to open after a 2 -week cold storage. Results suggest that bud blasting was at least partially due to lack of carbohydrates for the development of the 'Stargazer'

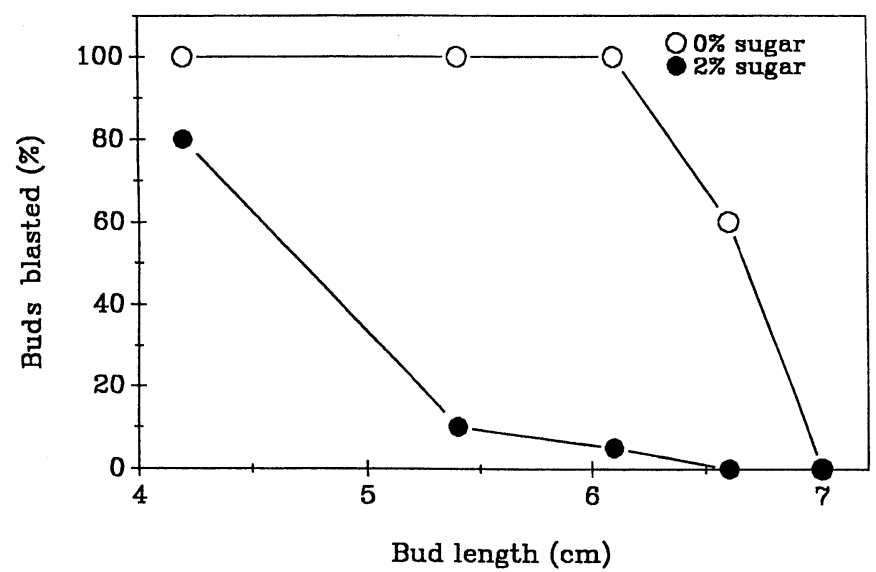

Fig. 1. Bud blasting of various stages of excised Oriental lily 'Stargazer' buds placed in solutions containing $0 \%$ or $2 \%$ sugar. All solutions contained $200 \mathrm{mg} \cdot \mathrm{L}^{-1} \mathrm{HQC}$.

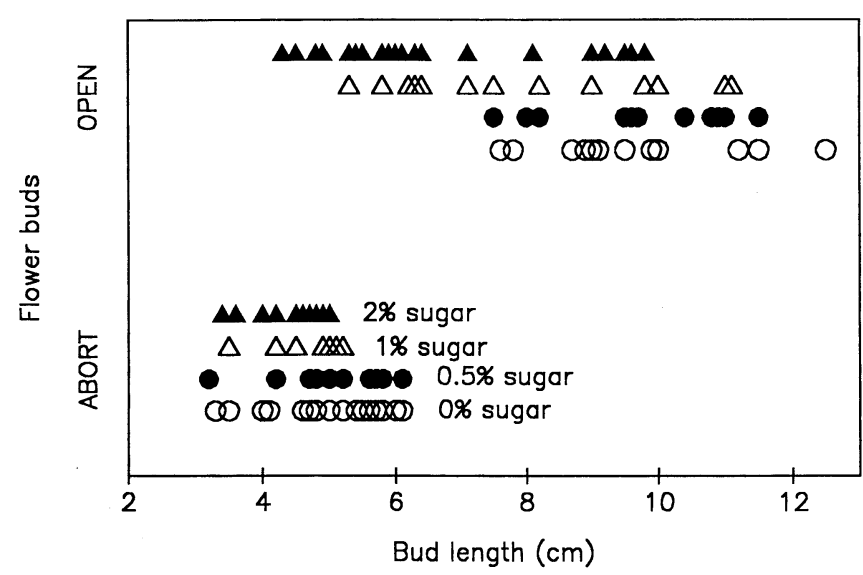

Fig. 2. Effects of sugar on the opening of excised Oriental lily 'Stargazer' buds when placed in solutions containing $0 \%, 0.5 \%, 1 \%$, or $2 \%$ sugar. Each data point represents a flower bud.

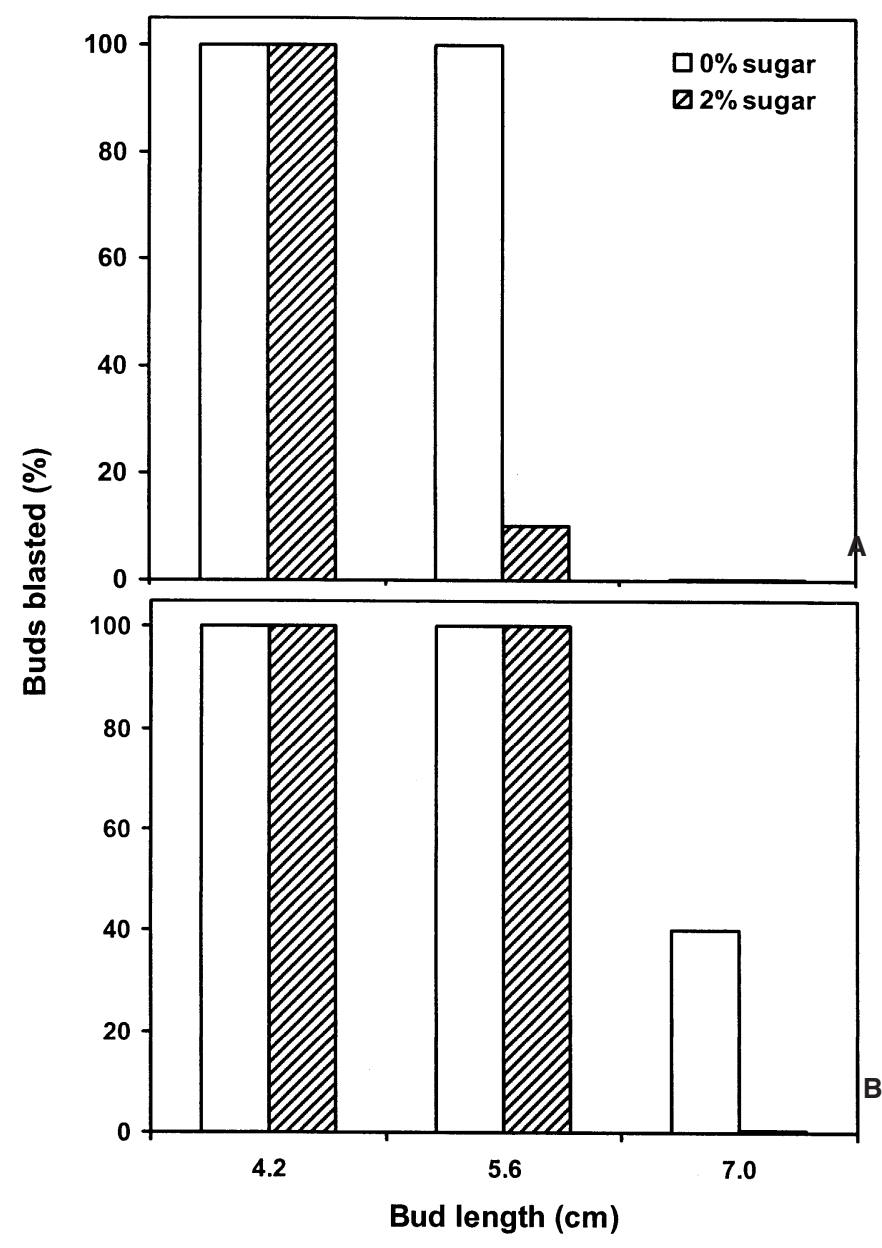

Fig. 3. Effects of sugar in the vase solution and cold storage on blasting of excised Oriental lily 'Stargazer' buds. Buds were immediately placed in solutions containing (A) $0 \%$ or $2 \%$ sugar plus $200 \mathrm{mg} \cdot \mathrm{L}^{-1} \mathrm{HQC}$ or (B) were cold-stored for 2 weeks before being transferred to the appropriate preservative solutions for postharvest evaluation. 
buds and that the use of exogenous sugar was advantageous but only in situations where carbohydrate was marginally limited.

Of the 25 postharvest experiments conducted on 'Stargazer', one variable, the percentage of buds blasted after a 2-week cold storage, varied greatly between experiments, ranging from $0 \%$ to $56 \%$, with an average of $\approx 30 \%$ bud blasting in most experiments. In most experiments, all of the third bud and none of the first bud on each stem blasted indicating, once again, that bud blasting was determined by the developmental stage of the buds. Measurement of the length of the third bud, taken from various experiments, indicated that bud length at the time of harvest ranged from 5.5 to $7.7 \mathrm{~cm}$. According to the excised bud experiments, these were the developmental stages that were susceptible to cold-storage-induced bud blasting (Fig. 3). Thus, the large variation in bud blasting between various experiments might be explained simply in that lily stems were harvested based on the coloration of the largest bud and the stage of the smallest bud was not taken into consideration. The harvesting stage of the inflorescence has been shown to contribute significantly to the variation in inflorescence longevity and the percentage of open flowers in several cultivars of Asiatic lilies (Lilium L.) (van der Meulen-Muisers and van Oeveren, 1997). In 'Apeldoorn' and 'Ladykiller', only $\approx 30 \%$ of the buds on freshly harvested stems developed to anthesis when inflorescences were harvested with the largest bud just starting to show color, whereas $85 \%$ and $99 \%$ of the buds of the same cultivars opened, respectively, when inflorescence were harvested when the most mature bud had reached anthesis. Unlike most species in which flowers for long-term storage or long-distance transport are harvested at a tighter-bud stage than that intended for local market, 'Stargazer' stems intended for storage should be harvested at a more developed stage.

Sugar and leaf quality. Light during cold storage increases levels of soluble carbohydrates in the leaves of potted 'Stargazer' and delays the development of post-storage leaf yellowing, indicating a relationship between carbohydrate levels and leaf yellowing (Ranwala and Miller, 2000). In cut flowers, the addition of sugar in the vase solution is a convenient method of adding soluble carbohydrates (Halevy and Mayak, 1979), but in cut 'Stargazer', 2\% sugar in the solution induced earlier development of leaf yellowing when compared to those in a sugarless solution

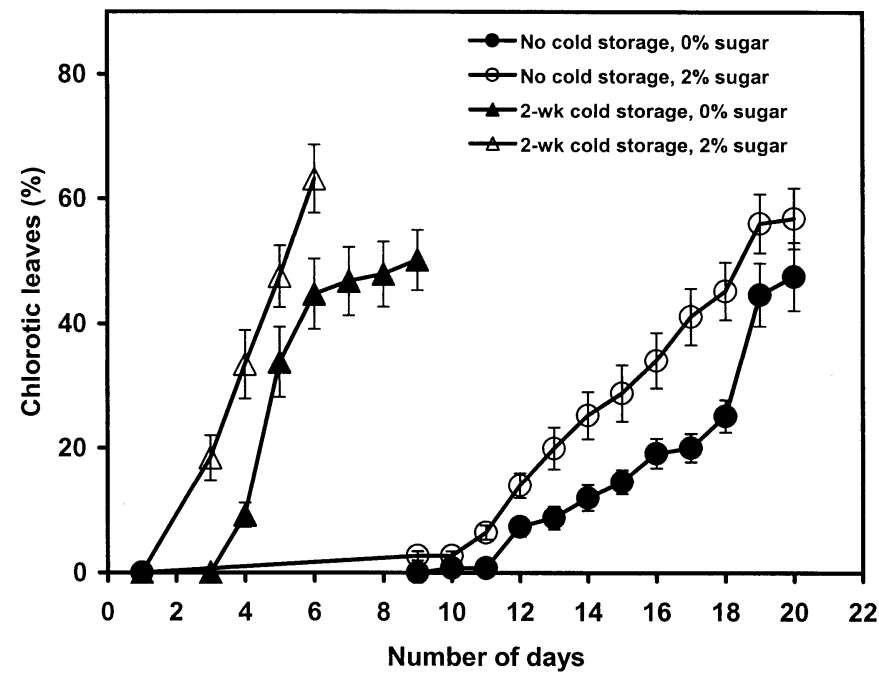

Fig. 4. Development of leaf yellowing in cut Oriental lily 'Stargazer' placed in solutions containing $0 \%$ or $2 \%$ sugar plus $200 \mathrm{mg} \cdot \mathrm{L}^{-1} \mathrm{HQC}$. Half of the stems were placed in a $3.3{ }^{\circ} \mathrm{C}$ room for 2 weeks.

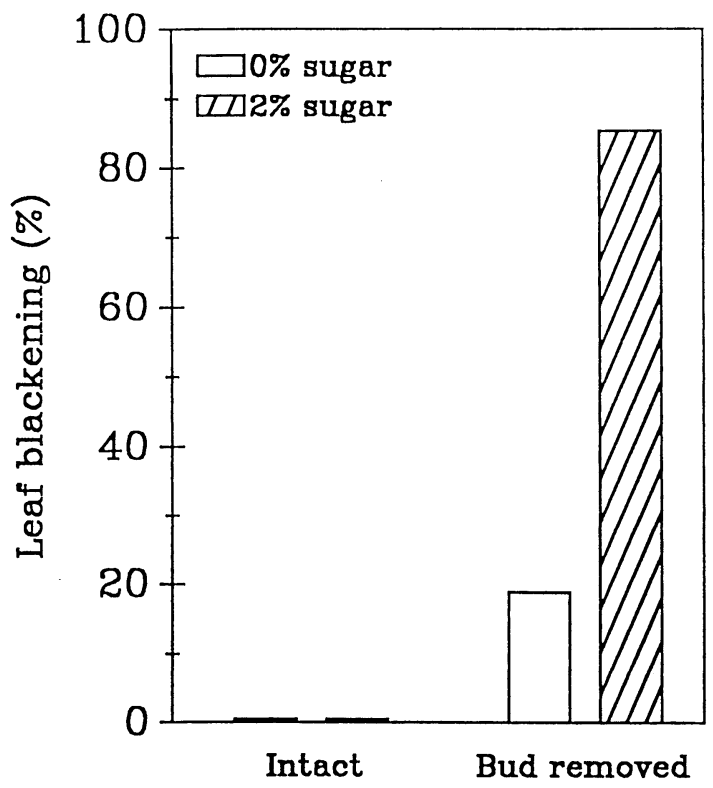

Fig. 6. Development of leaf blackening on Oriental lily 'Stargazer' stems placed in a solution containing $0 \%$ or $2 \%$ sugar plus $200 \mathrm{mg} \cdot \mathrm{L}^{-1} \mathrm{HQC}$. Buds were left intact or were removed from the inflorescence.

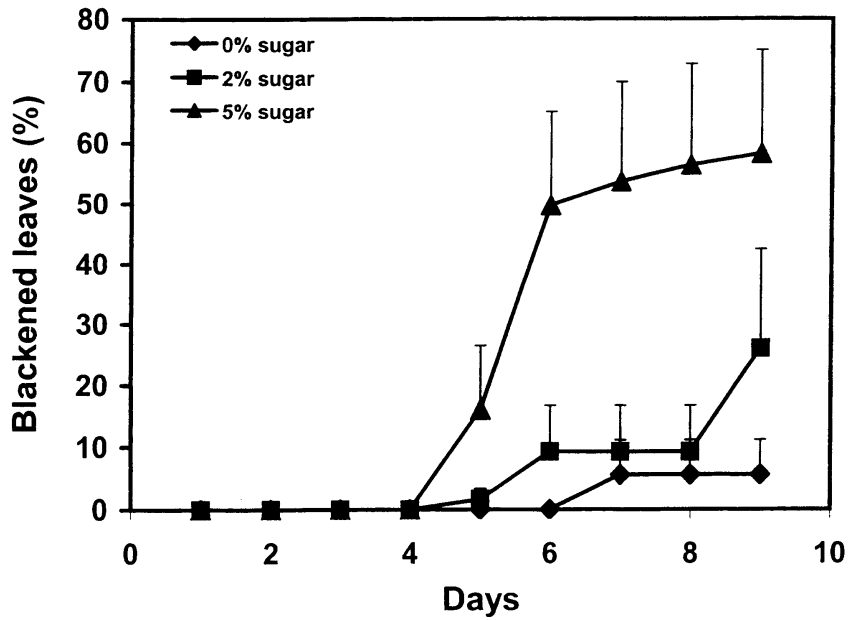

Fig. 5. Development of phytotoxic symptoms as leaf blackening on Oriental lily 'Stargazer' stems placed in a solution containing $0 \%, 2 \%$, or $5 \%$ sugar plus $200 \mathrm{mg} \cdot \mathrm{L}^{-1} \mathrm{HQC}$. All stems were cold stored in a $3.3^{\circ} \mathrm{C}$ dark cooler for 2 weeks.

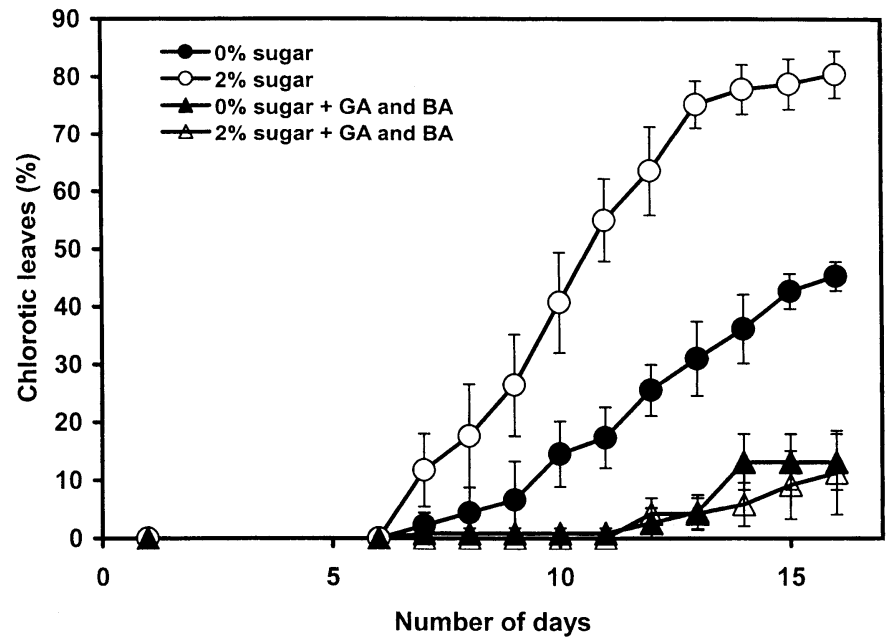

Fig. 7. Development of leaf yellowing in cut Oriental lily 'Stargazer' placed in solutions containing $0 \%$ or $2 \%$ sugar plus $200 \mathrm{mg} \cdot \mathrm{L}^{-1} \mathrm{HQC}$. Half of the stems were sprayed with a solution containing $50 \mathrm{mg} \cdot \mathrm{L}^{-1}$ each of $\mathrm{BA}$ and $\mathrm{GA}_{4+7}$. 
(Fig. 4). Higher concentrations of sucrose (5\%) caused leaf blackening (starting as blackening of partial leaf area and eventually resulting in blackening of the entire leaves indicating phytotoxic reactions to high levels of sugar (Fig. 5). Leaf scorch and necrotic lesions, as well as other forms of phytotoxic symptoms, have been reported in cut chrysanthemums (Chrysanthemum xmorifolium Ramat.) and zinnias (Zinnia elegans Jacq) when placed in vase solution containing $>2 \%$ sugar (Kofranek and Halevy, 1981; Stimart and Brown, 1982). Blackening of leaves in 'Stargazer' also developed in an experiment in which buds were removed and stems were placed in a $2 \%$ sugar solution (Fig. 6), again, as a result of the accumulation of excess sugar in the leaves. Results, thus, support anecdotal comments from florists that sugar in vase solution enhances leaf yellowing and thus provides the reason for using sugarless solution in the handling of cut lilies. However, spraying leaves with a growth regulator solution containing both $\mathrm{BA}$ and $\mathrm{GA}_{4+7}$ reduced leaf yellowing induced by sugar in the vase solution (Fig. 7), cold storage (Han, 2001; Ranwala and Miller, 1998), and normal leaf senescence (Celikel et al., 2002).

In conclusion, addition of sugar to the vase solution improved the intensity of the petal color but did not improve bud opening, longevity, or size of non-cold-stored 'Stargazer' harvested at the commercial marketing stage. In cold-stored stems, while sugar in the vase did not reduce the cold-storage-induced bud blasting, it did enable some buds, which would otherwise have only opened partially to open fully. When cut stems were harvested at a stage containing buds $<6.1 \mathrm{~cm}$, bud blasting of those small buds occurred due to lack of carbohydrates for proper bud development. Addition of $2 \%$ sugar to the vase significantly increased the opening of the small buds. The critical stage for bud opening, however, increased to $>7.0$ $\mathrm{cm}$ on cold-stored stems, indicating that stems intended for cold storage should be harvested at a later stage. Defoliation of Oriental lily to eliminate unsightly yellow leaves, a common practice by retail florists, reduced the intensity of petal color but had no affect on bud opening and longevity of buds, size of flowers, and vase life of the stems. Addition of sugar to the vase solution of defoliated stems not only restored the color on the petals but increased the size of the open flowers. For best petal coloration and leaf quality, cut stems should be placed in a solution containing $2 \%$ sugar and leaves should be left intact and sprayed with a solution containing $\mathrm{BA}$ and $\mathrm{GA}_{4+7}$.

\section{Literature Cited}

Asen, S. 1975. Factors affecting flower color. Acta Hort. 41:57-68.

Boo, H., Y. Tomitaka, M. Ichimura, and M. Kimura. 1997. Effect of environmental factors on anthocyanin synthesis and sugar content in Cichorium intybus L. var. foliosum. Environ. Control Biol. 35:91-98.

Celikel, F.G., L.L. Dodge, and M.S. Reid. 2002. Efficacy of 1-MCP (1-methylcyclopropene) and Promalin for extending the post-harvest life of Oriental lilies (Lilium X 'Mona Lisa' and 'Stargazer'). Scientia Hort. 93:149-155.

Dedaldechamp, F., C. Uhel, and J. Macheix. 1995. Enhancement of anthocyanin synthesis and dihydroflavonol reductase (DFR) activity in response to phosphate deprivation in grape cell suspensions. Phytochemistry 40:1357-1360.

Goszczynska, D., H. Itzhaki, A. Borochov, and A.H. Halevy. 1990. Effects of sugar on physical and compositional properties of rose petal membranes. Scientia Hort. 43:313-320.

Halevy, A.H. and S. Mayak. 1979. Senescence and postharvest physiology of cut flowers. I. Hort. Rev. 1:204-236.

Han, S.S. 2001. Benzyladenine and gibberellins improve postharvest quality of cut Asiatic and Oriental lilies. HortScience 36:741-745.

Kawabata, S., Y. Kusuhara, Y. Li, and R. Sakiyama. 1999. The regulation of anthocyanin biosynthesis in Eustoma grandiflorum under low light conditions. J. Jpn. Soc. Hort. Sci. 68:519-526.

Kofranek, A.M. 1985. Postharvest physiology of cut flowers, p. 239-252. In: S.P. Singh (ed.). Short season flowering plants. B.R. Publishing, Dehli, India.

Kofranek, A.M. and A.H. Halevy. 1981. Chemical treatment of chrysanthemums before shipment. Acta Hort. 113:89-95.

Lalonde, S., E. Boles, H. Hellmann, L. Barker, J.W. Patrick, and W.B. Frommer. 1999. The dual function of sugar carriers: Transport and sugar sensing. Plant Cell. 11:707-726.

Moalem, B.D., G. Tamari, D.Y. Leitner, A. Borochov, and D. Weiss. 1997. Sugar-dependent gibberellin-induced chalcone synthase gene expression in petunia corollas. Plant Physiol. 113:419-424.

Neta, S.I., O. Shoseyov, and D. Weiss. 2000. Sugars enhance the expression of gibberellin-induced genes in developing petunia flowers. Physiol. Plant. 109:196-202.

Nichols, R. 1973. Senescence of the cut carnation flower: Respiration and sugar status. J. Hort. Sci. 48:111-121.

Ranwala, A.P. and W.B. Miller. 1998. Gibberell$\operatorname{lin}_{4+7}$, benzyladenine, and supplement light improve postharvest leaf and flower quality of cold-stored 'Stargazer' hybrid lilies. J. Amer. Soc. Hort. 123:563-568.

Ranwala, A.P. and W.B. Miller. 2000. Preventive mechanisms of gibberellin ${ }_{4+7}$ and light on lowtemperature-induced leaf senescence in Lilium cv. Stargazer. Postharvest Biol. Technol. 19: 85-92.

SAS Institute. 1999. SAS/STAT user's guide. Ver. 8. SAS Inst., Cary, N.C.

Serek, M., R.B. Jones, and M.S. Reid. 1994. Role of ethylene in opening and senescence of Gladiolus sp. flowers. J. Amer. Soc. Hort. Sci. 119: 1014-1019.

Song, C.Y., C.S. Bang, S.K. Chung, Y.J. Kim, D.C. Lee, and J.S. Lee. 1996. Effects of postharvest pretreatments and preservative solutions on vase life and flower quality of Asiatic hybrid lily. Acta Hort. 414:277-285.

Spikman, G. 1989. Development and ethylene production of buds and florets of cut freesia inflorescence as influenced by silver thiosulphate, aminoethoxyvinylglucine and sucrose. Scientia Hort. 39:73-81.

Stewart, R.N., K.H. Norris, and S. Asen. 1975. Microspectrophotometric measurement of $\mathrm{pH}$ and $\mathrm{pH}$ effect on color of petal epidermal cells. Phytochemistry 14:937-942.

Stimart, D.P. and D.J. Brown. 1982. Regulation of postharvest flower senescence in Zinnia elegans Jacq. Scientia Hort. 17:391-396.

van der Meulen-Muisers, J.J.M. and J.C. van Oeveren. 1997. Influence of bulb stock origin, inflorescence harvest stage and postharvest evaluation conditions on cut flower longevity of Asiatic hybrid lilies. J. Amer. Soc. Hort. Sci. 112:368-372.

van der Meulen-Muisers, J.J.M., J.C. van Oeveren, L.H.W. van der Plas, and J.M. van Tuyl. 2001. Postharvest flower development in Asiatic hybrid lilies as related to tepal carbohydrate status. Postharvest Biol. Technol. 21:201-211.

van der Meulen-Muisers, J.J.M., J.C. van Oeveren, B.B. Meijkamp, and F.H.M. Derks. 1995. Effect of floral bud reduction on individual flower longevity in Asiatic hybrid lilies. Acta Hort. 405:46-57.

Vitrac, X., F. Larronde, S. Krisa, A. Decendit, G. Deffieux, and J.M. Merillon. 2000. Sugar sensing and $\mathrm{Ca}^{+2}$-calmodulin requirement in Vitis vinifera cells producing anthocyanins. Phytochemistry 53:659-665.

Woodson, W.R. and H. Wang. 1987. Invertases of carnation petals: Partial purification, characterization and changes in activity during petal growth. Physiol. Plant. 71:224-228. 